DOI: $10.30727 / 0235-1188-2020-63-3-95-104$

Original research paper

Оригинальная исследовательская статья

\title{
The Modernity of Andrei Platonov: On the Understanding of the Writer's Essential Ideas
}

\author{
I.I. Myurberg \\ Institute of Philosophy, Russian Academy of Sciences, Moscow, Russia
}

\begin{abstract}
The article analyzes Andrei Platonov's heritage by approaching his literary fiction as a manifestation of a holistic philosophic message. Viewing it from this angle, we can assume that the central idea of Platonov's work is his reflection concerning the crisis of individualism, as well as revival of collectivist principles in Soviet Russia (later, this process would be labeled as "ionization" of contemporary society). In this regard, the first object of study was to analyze the prevailing approach toward Platonov's genius (primarily based on the writer's unique diction). We challenge this approach, showing that Platonov's language serves more general concepts than those that can be revealed in his works by purely philological study. Further, we demonstrate that the phenomenon to comprehend is potential relevance of the writer's inner world to the philosophical structure of European Modernity and, more specifically, to the theory of the stages of modern society development. This part of the study yields the conclusion that Platonov's concept of "ionization," in fact, logically complements the theory of European development put forward in the $20^{\text {th }}$ century, that is, the theory of the transition from "individualization" to "atomization" ("massification") of society. Therefore, the writer's creative impulse is empowered by his aspiration to restore the lost social bonds; yet this does not make him, a utopian daydreamer. In his works, the "ionization" of society is represented as a dramatically contradictory process, as an important part of cultural and political movement (individualization - atomization - ionization) in post-revolutionary society. Viewed from this perspective, the writer remains a participant of the philosophical discourse on Modernity, and not only of Russian Modernity, but its European implementation, too.
\end{abstract}

Keywords: Modernity, ionization, individualization, atomization, collectivism, mass society, loss of personality, "Russian idea."

Irina I. Myurberg - D.Sc. in Political Philosophy, Leading Research Fellow, Department of History of Political Philosophy, Institute of Philosophy, Russian Academy of Sciences. 
Филос. науки / Russ. J. Philos. Sci. 2020. 63(3) Проза как философия: Андрей Платонов irina.myrberg@gmail.com

http://orcid.org/0000-0001-5606-6488

For citation: Myrberg I.I. (2020) The Modernity of Andrei Platonov: On the Understanding of the Writer's Essential Ideas. Russian Journal of Philosophical Sciences = Filosofskie nauki. Vol. 63, no. 3, pp. 95-104.

DOI: 10.30727/0235-1188-2020-63-3-95-104

\title{
Современность Андрея Платонова: наброски к осмыслению предмета творчества писателя
}

\author{
И.И. Мюрберг
}

Институт философии РАН, Россия

\section{Аннотация}

В статье предпринята попытка анализа творчества Андрея Платонова с позиций признания его литературного наследия как выражения некоего философски целостного послания. С этой точки зрения исследуется гипотеза, согласно которой в платоновских произведениях роль центральной идеи принадлежит тезису о кризисе индивидуализма и возрождении коллективистского начала в современной ему России (позже этот процесс получил название «ионизации» общества). В этой связи первым объектом изучения стало преобладающее отношение к гениальности Платонова как характеристике, основанной на уникальности художественного языка писателя; показано, что язык Платонова обслуживает более общие понятия, чем те, которые способны выявить в его работах собственно филологические исследования. Развивается мысль о соразмерности духовного мира писателя структуре философского постижения феномена европейского модерна, конкретней - представлениям о стадиях развития современного общества. Эта часть исследования приводит к выводу о том, что развиваемая Платоновым тема «ионизации» органично дополняет выдвинутую в XX в. теорию европейского развития - от «индивидуализации» к «атомизации» («массовизации») общества. Соответственно, творческий импульс писателя в огромной степени подпитывается жаждой восстановления утраченной социальности, что отнюдь не делает его мечтателем-утопистом. В его произведениях «ионизация» социума представлена как важная часть культурно-политической динамики постреволюционного общества (индивидуализация - атомизация ионизация), показана во всем драматизме этого противоречивого процесса. И в этом ракурсе писатель остается актуальным участником философского дискурса о современности - не только отечественной, но и общеевропейской. 
Ключевые слова: современность, ионизация, индивидуализация, атомизация, коллективизм, массовое общество, утрата личности, «русская идея».

Мюрберг Ирина Игоревна - доктор политических наук, ведущий научный сотрудник сектора истории политической философии Института философии РАН.

irina.myrberg@gmail.com

http://orcid.org/0000-0001-5606-6488

Для цитирования: Мюрберг И.И. Современность Андрея Платонова: наброски к осмыслению предмета творчества писателя // Философские науки. 2020. Т. 63. № 3. С. 95-104.

DOI: $10.30727 / 0235-1188-2020-63-3-95-104$

\section{Introduction}

Andrei Platonov (1899-1951) is an established classic of Russian literature. Suffice to refer to literary critic Dmitry Bykov who stated that Platonov managed to deliver a new message about human nature. This claim infers that Platonov duly opens the list of writers and philosophers who are relevant to our contemporaneity. This assessment comes from literary history, yet challenges philosophers to clarify the philosophical message that is embodied in the writer's unique literary output.

Regarding Dmitry Bykov's opinion, we see that the literary critic very clearly proposes his own interpretation of Platonov's contribution to philosophical thought: "He [Platonov] discovered that human masses would become the major literary character of the $20^{\text {th }}$ century (and perhaps of the subsequent epochs); that the main thing in humans is their spiritual and, most importantly, physical inclination to merge with other people; Platonov describes how this mass arises, acts, quarrels, disintegrates, and converges. Actually, this accretion of masses and decay of personality is his main subject. I do not think that this was clear in his lifetime, and he himself did not fully realize it, but now seems to be the right time to admit it" [Bykov 2016]. I would like to immediately highlight my points of agreement with so tricky a statement made by the famous literary critic; these points of agreement because of this statement are loaded with ideas that are extremely important and significant, for example, for modern political philosophy, as an optimal way to conceptualize Modernity [Kapustin 1998]. However, it is necessary, in the first place, to review other known attempts to comprehend the essence of Platonov's genius.

\section{The role of language in Platonov's works}

The belief that the genius of the writer is almost completely captured in his language is, indeed, commonplace in philological circles. 
This belief causes some researchers to make a sort of "inventory" for lexical and stylistic techniques used in his works (semantic reduction, comic occasional usage, shift in logic, inconsistent grouping, etc.); these techniques are purportedly aimed at "more serious dialogue with society," making the author's reflections "accessible to the mass reader" [Matveeva 2011, 12-17]. Others (including fiction author Tatiana Tolstaya) emphasize the unique nature of Platonov's work on his text: "The huge difficulty of understanding Platonov is due to the fact that he invented his own, special and unique, language, although he used only standard Russian and never resorted to neologisms" [Tolstaya 2000]; at the same time, however, the unpredictable novelty of his feelings and thoughts derives from "minimal departures from the norm" that are to be found in nearly every line of his texts.

It should be noted that the interest of critics in the language of Platonov's narratives rather early went beyond philology as such and gradually gained a cultural and political bent. It is already obvious in the famous afterword to the novel The Foundation Pit (Kotlovan), written in 1973 by Joseph Brodsky, that the novelty of Platonov's language served as a means of understanding cultural and civilizational processes in Russian society in the first third of the $20^{\text {th }}$ century; at the same time, Brodsky attributed part of the responsibility for the spiritual state of society to the linguistic novelties of the revolutionized society that came to use its Newspeak: "It is not self-centered individuals, whom God himself and literary tradition provided with crisis-ridden consciousness, but representatives of the traditionally inanimate mass who, according to Platonov, expose the philosophy of the absurd, thanks to which this philosophy becomes much more convincing and completely intolerable due to its scale. Unlike Kafka, Joyce, or, say, Beckett, who tell us about quite natural tragedies of their 'alter egos,' Platonov speaks of a nation that has become, in some way, a victim of its language, or rather of the fact that the language itself, has given rise to an imaginary world and has fallen into a grammatical dependence on it" [Brodsky 2014]. Thus, since Brodsky, the topic of "mass" (a mass society whose mentality is largely formed, if not generated by the "deformed" modern language) entered the sphere of literary and philosophical interpretations of Platonov's poetic language. At the same time, it is striking that, according to Brodsky, all that indicates the "tragedies of language," typical of the $20^{\text {th }}$ century, appear to be phenomena heterogeneous in their nature: in the West, these tragedies are "natural," because they are born in the depths of consciousness of creative individuals; while in terms of the emerging Soviet society of the 1930s, the object (and, partially, a victim) of the language is, according to the poet, nation as a whole; in other words, there is quite a different type of cultural historical development. Such 


\section{I.I. MYURBERG. The Modernity of Andrei Platonov: On the Understanding...}

a comparison, in a sense, represents the opposition of West European (individualistic) development to the East European drift to collectivistic blighted existence.

The idea of the depersonalized Russian universe of the $20^{\text {th }}$ century which is reflected, according to Brodsky, in Platonov's language, meant to tell us about "extra-personal, folkloristic and, to a certain extent, akin to ancient (or any other) mythology" [Brodsky 2014] - was convincingly criticized by philologist N.G. Poltavtseva. Her analysis is related to the findings of British researcher Thomas Osborne [Osborne 2003, 123-136]: "For Thomas Osborne, Bulgakov, Leonov, and Babel are people who work with language, but they primarily perform intellectual work. Platonov is not a writer in the proper sense of the word: he is not a narrator of a fabula. He is not making his plot entertaining, eventful, or rich in imagery. To represent an event, he uses his whole organism as well as the capacities of his artistic imagination. And in this representation he (as Osborne believes) falls out of the general picture of other representatives of Soviet literature" [Poltavtseva 2010]. Our interest in Platonov, as is emphasized by Poltavtseva, stems from the fact that he managed to make "instrumental" not only consciousness but also subconsciousness of his epoch. This prompted Platonov's strong predilection for a reflexive view of reality; it was this predisposition that allowed the writer not to fall a victim to the epoch. And after all, his prose is about the time when staying alive was equivalent to the experience of descent into hell, to use the metaphor of V.N. Porus (Porus referred to Kolyma Tales by Varlam Shalamov) [Porus 2019, 175-228]. There, in "hell," a man is just an object, a potential victim. The man, writes Alain Badiou, "is the being who is capable of recognizing himself as a victim" [Badiou 2001, 10]. But it is, for Badiou, nothing more than a criminal half-truth about human personality: according to the same Shalamov, the whole truth is not only which is said about the torturers in Kolyma (GULAG), "it is because the victims have indeed become such animals. What had to be done for this to happen has indeed been done. That some nevertheless remain human beings, and testify to that effect, is a confirmed fact" [Badiou 2001, 11].

Badiou's reflections make it necessary to see in the established tradition of commentaries to Platonov's works a certain similarity to the ancient Indian parable of blind wise men exploring an elephant: it seems, no matter how hard one tries to construct the image of a whole piece-by-piece, success remains unattainable without participation of at least one sighted person. Such "sightedness," in analyzing Platonov's legacy, implies that, first of all, everything written by him should be perceived and accepted as a whole and by all our feelings - and only after that can one dare to analytically discern from this whole Platonov's unique concepts and topics. The effect achieved is only comparable to 
what Bykov achieves by introducing ionization concept. Unfortunately, such a meaningful concept as ionization is partially devalued by its author [Bykov 2019]; Bykov is well aware that ionization transfers him to the sphere of political existence: and upon approaching this sphere, he hurries to proclaim his own political creed. Regretfully, turning to politics seems to mislead him as an analyst.

\section{Platonov and the phenomenon of ionization}

The term ionization coined by Bykov cannot be understood without reference to the conceptual macrohistory of European Modernity and its factography. Ionization is not among the terms used by representatives of social and humanitarian knowledge; however, logically and historically, it constitutes a tandem with atomization (the concept that gained scientific meaning in the era of rapid development of physics and other natural sciences; later, the word became common not only in natural but also in social sciences and humanities). It makes sense to review the general logic of borrowing terms from the science about inanimate objects onto the humanities. Thus, expansion of the concept of atomization meant extending awareness about changing value priorities to specifically modern social process. Early Modernity used to be proud of the individualized personality, the product of European societal growth. For two or three centuries, the theme of individualism remained emotionally colored by this pride. However, a retrospective view of the transformation that was underlying individualization makes us revise its outcome (the "society of individuals" [Elias 1991]); now, this society looks no more than a logical (and apparently the only possible) way to preserve the archaic elements of government of the European Middle Ages; this is achieved by preventing a complete demolition of the institute of state authority. Let us recall that individualization of European society was preceded by a deep crisis both of society and of individual persons as its members. So, the word "individual" sounded proud to those Europeans who felt themselves as participants of the transformation. And it continued to sound proud until the beginning of the $20^{\text {th }}$ century, when the principle of methodological individualism [Weber 1978, 4-21], which permeated the vital foundations of European society, started to lose its relevance. For philosophers, this period is most memorable by another process (it was related also to challenged individualism) - the decay of classical and the rise of non-classical European philosophy. Noteworthy, V.N. Porus, who deals with this phenomenon discussing the language of Platonov's works, prefers to analyze its underlying meanings in terms of truth and falsity. According to Porus, Platonov's genius partly lies in the fact that he always manages to speak in an authentic language. The writer's works are sensitive to cultural shifts that are produced by Modernity. Platonov's inner world is in resonance 


\section{I.I. MYURBERG. The Modernity of Andrei Platonov: On the Understanding...}

with some concepts and approaches of non-classical philosophy (nowadays, this is confirmed by many commentators of his texts). But what is the core of this resonance?

One answer is prompted to us by Bykov's nontrivial idea of ionization - it looks quite integrated into the historical/cultural conceptual triad: individualization-atomization-ionization. The first two terms are historically precedent and represent a "background" of ionization. Viewed together, they symbolize three successive stages of development. Thus, the concept of the individual (individualization) that emerged simultaneously with Modernity had its own transformative destiny, and it is significant as an element of a certain historical context. Boundaries to this context were set by the $20^{\text {th }}$ century, which gave rise to ethical-political/socio-cultural neologisms: "atomization" and "mass" (not to be confused with the Marxist "masses"). Further on, the theory of mass society (it emerged in the $20^{\text {th }}$ century) was the result of a critical rethinking of the individualization process in Europe (to reveal what it was and what historical role it played). Thus, the abovementioned theory of mass society has to do with a new awareness, according to which the era of modernism caused serious damage to the social sphere; formed in the process of liberation from the shackles of medieval society, these and other embodiments of "free individuality" now looked as hostages of social atomism. The decay of traditional society, instead of the expected rise of individuality, resulted in an unprecedented leveling of tastes, interests, and moral attitudes among members of society; the main issue on the "agenda" in the $20^{\text {th }}$ century became the situation of universal mutual alienation - instead of the desired individual autonomy of citizens. The necessity to face unexpected challenges of modernization brought more linguistic novelties to life; actually, these were synonymous to the Latin individuum (indivisible), but, this time, the synonyms were borrowed from Ancient Greek atom ( $\not \tau o \mu о \varsigma$ - "indivisible"). Thus, our modernity has recorded a change in the attitude of Europeans toward the initial term. And this was due to the historically specific consequences of pervasive individualization. The leading thinkers of the $20^{\text {th }}$ century (R. Merton [Merton 1938], J. Ortega-y-Gasset [Ortega-y-Gasset 1932], J. Baudrillard [Baudrillard 1983], and many others) disclosed to the contemporaries the true dimensions of the social and cultural scourge that is known to us as "mass society."

Almost any contemporary author who discusses mass society becomes aware of the serious shift described by N. Elias as the loss of "we-perspective," and each researcher sees it as a serious problem still unresolved and fraught with catastrophes in future. This concern constitutes the cultural and political background against which 
Andrei Platonov's creative output can be presented in the entirety of its contemporary impact. Thus, according to N.G. Poltavtseva, there are, indeed, a number of works where the writer "implements some general, symbolic principles of the imaginary, some symbolism of human existence expressed in literary 'fictionality' as such," and this "seems much more important and interesting as well as partially explanatory of his recognition by readers as a writer of universal cultural relevance - the fact which we have witnessed for quite a long time" [Poltavtseva 2010].

No less convincing is Dmitry Bykov when he argues that only today Andrei Platonov has been revealed as a really modern author; for it was indeed in late Modernity that (objective) need for at least partial restoration of lost sociality was openly declared. And it seems to be that what Bykov, with a grain of irony, calls "ionization" of the atomized public body, which is actually eager to reunite with itself nowadays. The genius of Platonov, who was very sensitive to this need, lies, not least, in the artistic means he chose: the method of "fantastic realism," which accounts for the purposeful grotesque, implausibility of the world in which Platonov's characters live - all of them bring to every reader an awareness of the "borderline" (in the existentialist sense) nature of their situation; and, at the same time, it prompts the insight implied in available studies of Russian history that, by and large, "there is no villainous [Hoffmann's] Zaches at the head of the regime (that is, there is a Zaches, but he does not matter). Instead, there is a collective body of the people, eager for ionization [italics added], a collective Chevengur, eager to come true" [Bykov 2016]. It is noteworthy that Platonov does not (and, indeed, cannot) offer an unambiguous (and ahistorical) assessment for the cultural and historical "fact" that he discovered. For example, in the context of Chevengurian communism, ionization is a "process with a human face."

Here is an example from Chevengur. Yakov Titych, an old man, developed severe abdominal pain. "Yakov Titych sighed, sorry for his body and the people who were around him. He saw how when he was so down and aching his torso lay alone on the floor with people standing near him. Each of them had a torso of his own, and yet none of them knew where to direct his body during Yakov Titych's misery [...] here Chepurny sighed too. Dvanov might at least help" [Platonov 1978a, 278-279]. And Dvanov did help: his figure, full of compassion for the sick man, had a unifying effect; and it was enough for the old man to complain about the raindrops from the leaking roof, and general helplessness was replaced with the universal efficiency: some guys got to the roof, others went down to the cellar to fetch the hammer. And although the moon was already shining in the sky, the sound of the hammer attracted Chevengurians from everywhere - to watch, for the 


\section{I.I. MYURBERG. The Modernity of Andrei Platonov: On the Understanding...}

first time in the history of "communism," people working. All those who came were met with Chepurny's assurances that Gopner "“didn't start hammering to get rich or to be useful. He just didn't have anything to give Yakov Titych, so he began patching the holes in the roof over his head. That's permissible.' 'That's permissible,' the men answered. Then they stood around until midnight, when Gopner came down from the roof. [...] The Chevengurians slept the remaining night. Their sleep was calm and filled with consolation" [Platonov 1978a, 279-280]. This episode brought a radical change to Chevengur, and the people were no longer ashamed of labor as a "bourgeois" occupation. That night showed to everyone that selfless work for the benefit of the neighbor can turn labor into free creativity; it gave them promise of true social rebirth.

Somehow, Bykov presents us with what he believes to be another reality underlying Platonov's "ionization" idea. The final scene of the The Epifan Locks [Palatonov 1978b], a novella offset in Russia under Peter the Great, - the "merger" of the unfortunate engineer with his monstrous torturer (the one expected to act as an executioner authorized by the Czar) - it seems, according to the publicist, to attest Platonov's grim irony about the supposed timelessness of the "Russian idea."

\section{Final remarks}

Trying to describe Platonov as a thinker, we cannot deny his numerous creative findings, including most ambiguous "freaks of imagination" - true artistry is always imbued with diversity of insights. At the same time, it is important to divide the tasks of our own research, to distinguish between simply commenting on the products of the author's imagination and paying tribute to the writer's whole body of works. In the latter case, it is necessary to note that it is typical of Platonov as a thinker, to work on the internal systematization of his most important topics of research. Thus, his anxiety about the atomization that has befallen Russia, as well as his hope to overcome it in future, can be judged by how clearly he has distinguished different objects of study in specific works (Russia of Peter the Great in the novella The Epifan Locks [Platonov 1978b]), on the one hand, and Russia of the 1920s-1930s, on the other; the latter epoch is subdivided by the author into separate studies concerning (a) the historical center of the country (novel Chevengur [Platonov 1978a]) and (b) its multinational periphery (novel Soul, or Dzhan [Platonov 2008]). More detailed analysis of these different objects of the author's interest remain beyond the scope of the present paper. But even the initial approach to the topic is enough to rule out the possibility that Platonov could view Russia as a country of "eternal return," which would reject any change for the better. 


\section{REFERENCES}

Badiou A. (2001) Ethics: An Essay on the Understanding of Evil (P. Hallward, Trans.). London: Verso.

Baudrillard J. (1983) In the Shadow of the Silent Majorities, Or, the End of the Social (P. Foss, J. Johnston, \& P. Patton, Trans.). New York: Semiotext(e).

Brodsky J. (2014) Afterword to The Foundation Pit by A. Platonov. Bibliotechnoye delo. No. 24, pp. 23-24 (in Russian).

Bykov D. (2016) Andrei Platonov. Diletant. No. 2, pp. 90-95 (in Russian).

Bykov D. (2019, December 20) Odin. Echo of Moscow. Retrieved from https://echo.msk.ru/programs/odin/2556593-echo/ (in Russian).

Elias N. (1991) The Society of Individuals. Oxford: Blackwell.

Kapustin B.G. (1998) Modernity as a Political Philosophy. Moscow: ROSSPEN (in Russian).

Matveeva I.I. (2011) The Comic Language of the Characters of Andrei Platonov. Russkaya rech'. No. 4, pp. 13-17 (in Russian).

Merton R.K. (1938) Social Structure and Anomie. American Sociological Review. Vol. 3, no. 5, pp. 672-682.

Ortega-y-Gasset J. (1932) The Revolt of the Masses. London: Allen and Unwin.

Osborne T. (2003) Utopia, Counter-Utopia. History of the Human Sciences. Vol. 16, no. 1, pp. 123-136.

Platonov A.P. (1978a) Chevengur (A. Olcott, Trans.) Ann Arbor: Ardis.

Platonov A.P. (1978b) The Epifan Locks (M. Jordan, Trans.). In: Platonov A.P. Collected Works (pp. 223-256). Ann Arbor: Ardis.

Platonov A.P. (2008) Soul and Other Stories (R. Chandler, E. Chandler, A. Livingstone, O. Meerson, \& E. Naiman, Trans.) New York: New York Review Books.

Poltavtseva N.G. (2010) The Phenomenon of Andrei Platonov in the Context of the $20^{\text {th }}$ Century Culture. In: Works of the Russian Anthropological School. Issue 7 (pp. 206-243). Moscow: Russian State Universities for the Humanities (in Russian).

Porus V.N. (2019) Two Cases of the Descent into Hell: Andrei Platonov and Varlam Shalamov. In: Neretina S.S., Nickol'sky S.A, \& Porus V.N. Philosophical Anthropology of Andrei Platonov (pp. 175-228). Moscw: Institute of Philosophy, Russian Academy of Sciences (in Russian).

Tolstaya T. (2000) Out of This World. The New York Review of Books. Vol. 47, no. 6.

Weber M. (1978) Economy and Society. Berkeley: University of California Press. 